\title{
Study of bio-oils and solids from flash pyrolysis of sewage sludges
}

\author{
E. Pokorna ${ }^{a}$, N. Postelmans ${ }^{b}$, P. Jenicek ${ }^{a}$, S. Schreurs ${ }^{c}$, R. Carleer ${ }^{\text {b }}$, J. Yperman ${ }^{\text {b,* }}$ \\ a ICP Prague, Department of Water Technology and Environmental Engineering, Technická 5, 16628 Prague 6-Dejvice, Czech Republic \\ ${ }^{\mathrm{b}}$ Lab of Applied and Analytical Chemistry, CMK, Hasselt University, Agoralaan Gebouw D, 3590 Diepenbeek, Belgium \\ ${ }^{\mathrm{c}} \mathrm{NuTeC}$, dept. IWT, XIOS, Agoralaan Gebouw H, 3590 Diepenbeek, Belgium
}

\section{A R T I C L E I N F O}

\section{Article history:}

Received 17 July 2008

Received in revised form 16 February 2009

Accepted 17 February 2009

Available online 6 March 2009

\section{Keywords:}

Sewage sludge

Flash pyrolysis

Bio-oil

\begin{abstract}
A B S T R A C T
The aim of this study was to evaluate the production of pyrolysis oil from three types of sewage sludges. The flash pyrolysis was performed at $500{ }^{\circ} \mathrm{C}$, the maximum oil yield was $43.1 \%$, and the water content in bio-oils obtained from secondary sludges was relatively low $-10.3 \%$ and $17.0 \%$. GC-MS results showed that pyrolytic bio-oils of studied sludges dominantly contained fatty acids and nitrogenous compounds with potential added value.

Obtained solids had high ash content and low calorific value which make them unattractive for use in incineration. FT-IR results showed that solids gave similar IR features as notified alumino silicates; utilization of these solids as adsorbents could be a potential valorization.
\end{abstract}

(c) 2009 Elsevier Ltd. All rights reserved.

\section{Introduction}

The management of municipal wastewater treatment sludges is a difficult and expensive problem. With aerobic treatment generally $0.5-1 \mathrm{~kg}$ of activated sludge is produced per kilogram of biological oxygen demand $\left(\mathrm{BOD}_{5}\right)[1,2]$. The solids typically contain $60-80 \%$ organic matter in primary sludge, $70 \%$ in activated (secondary) sludge and $40-50 \%$ in digested sludge [3]. Secondary sludge contains $32-41 \%$ proteins, $5-12 \%$ lipids and $15-30 \%$ carbohydrates; digested sludge comprises $10-21 \%$ proteins, $2-17 \%$ lipids and $15-30 \%$ carbohydrates $[3,4]$.

The common disposal processes for sewage sludge include land filling, land application and incineration. Disposal in landfills is still the most frequently chosen alternative for sludge in Europe [5]. Disposal by landfilling requires a lot of space and the soil has to be sealed adequately to prevent the leaching of toxic compounds. Land application or the use of sewage sludge as a fertilizer can result in the accumulation of pollutants, mostly toxic metals.

Thermal treatment methods (e.g. waste combustion) have been introduced to replace the land filling option. There are however limitations. One of the major barriers is the public worry that combustion processes may release volatile toxic matter into the near environment. For example, toxic heavy metals cannot be retained during the combustion process and will thus be deposited on particulate matter nearby the incineration installation. More toxic volatile organic compounds (VOC's) can be formed and released [6].

\footnotetext{
* Corresponding author. Tel.: +32 11 268374; fax: +32 11268323.

E-mail addresses: eva.pokorna@centrum.cz (E. Pokorna), jan.yperman@uhasselt.be (J. Yperman).
}

Several technologies, such as pyrolysis, are currently under investigation as an alternative to conventional combustion processes. Pyrolysis is the thermal decomposition of organic substances under oxygen-deficient circumstances [7]. Pyrolysis at relatively low temperature presents certain advantages over the other methods [8]. The volume of the solid residue is drastically reduced; the heavy metals present in the carbonaceous matrix are relatively resistant to natural lixiviation [9], the thermal treatment gives rise to gases and even bio-oils with a high energetic value so they can be used as potential fuels. The chemical properties of the bio-oil indicate it's potential to be used as a range of specialty and commodity chemicals such as fertilizers and resins [10].

Flash or fast pyrolysis is an approach to maximize the yield of liquid product. Pyrolysis oil derived from sludge in this way results in a dark brown liquid that consists of a complex mixture of oxygenated hydrocarbons. The liquid product can be stored until required or readily transported to where it can be most effectively utilized [11]. The economic viability of pyrolysis may be improved if value-added products could be produced from the solids (e.g. adsorbents), oil (e.g.. fertilizers) or gas (e.g. syn-gas) [12].

\section{Materials and methods}

\subsection{Material}

Three types of sludge were studied: (a) thickened excess activated sludge (AKP); (b) dewatered digested sludge (DIG) and (c) (OLDA) was collected as dried excessive activated sludge. AKP and DIG were dried at $105^{\circ} \mathrm{C}$ and then pulverized by hand-mill and stored in airtight containers. 


\subsection{Experimental apparatus and procedure}

The flash pyrolysis was performed in semi-continuous lab scale reactor consisting of three parts: the vertical reactor, the injection and the recuperation system [13].

Within the vertical stainless steel reactor of $2200 \mathrm{ml}, 700 \mathrm{~g}$ of white sand was used as heat transfer medium. Before use, this sand was dried at $105^{\circ} \mathrm{C}$. The sand was in constant motion during the entire process to ensure a homogeneous temperature sand bed operating system. This was realized by an Archimedical screw which is perforated systematically on its whole length. The reactor was heated by a tailored heating jacket. The gas flow in the reactor was $140 \mathrm{ml} / \mathrm{min}$ of $\mathrm{N}_{2}(2 \times 70 \mathrm{ml} / \mathrm{min})$ to guarantee an "oxygendeficient" environment. The nitrogen gas entered the reactor via two ways: firstly, via the hollow shaft of the Archimedical screw in the reactor, and secondly via the injection system for the biomass. As the sludge injection system was started, the nitrogen flow was stopped. There was an overpressure obtained due to the pyrolysis gases, resulting in an automatically flowing of the pyrolysis products to the condensation vessel.

The injection system was manufactured in stainless steel as well. It consisted of a container with a volume of $600 \mathrm{ml}$ and an injector. The sludge was injected into the reactor fed from the container via an Archimedical screw with a controlled feeding rate $(25 \mathrm{~Hz})$. In this way $200 \mathrm{~g}$ of dried sewage sludge was completely transferred to the reactor within $90 \mathrm{~s}$. The recuperation system (condensation vessel $(\mathrm{OV})$ ), was a stainless steel collector vessel with a volume of $580 \mathrm{ml}$ and was kept at room temperature. In-between the reactor and the collector, a small water cooler was constructed to quench the gases. At the output of the collector vessel, a cold trap made out of copper (kept at $-196^{\circ} \mathrm{C}$ with liquid nitrogen) was installed to collect the rest of condensable gases (cold finger - CF). The noncondensable gases escaped the recuperation system via the chimney.

\subsection{Analysis}

1. Thermogravimetric analysis (TGA) was used for analysing the sludges and solids with respect to their thermal behaviour. About $25 \mathrm{mg}$ of sample was pyrolysed under approximately $35 \mathrm{ml} / \mathrm{min}$ He flow at a heating rate of $20^{\circ} \mathrm{C} / \mathrm{min}$ from room temperature (RT) to $700^{\circ} \mathrm{C}$. For the determination of fixed carbon and ash content, the gas flow was switched to oxygen with further heating to $900{ }^{\circ} \mathrm{C}$ under the same heating rate of $20^{\circ} \mathrm{C} / \mathrm{min}$.

2. Ultimate analysis was used to determine the CHNS- and Ocontent.

3. Calorific value determination was performed to determine the Highest Heating Value (HHV) of the sludges, bio-oils and chars. Net calorific values in terms of DIN norm 51900-3 [14] were also calculated.

4. GC-MS analysis - the bio-oils were dissolved in methanol and analyzed by GC/MS. The GC/MS instrument was a quadrupole mass spectrometer with $\mathrm{He}$ as the carrier gas and a capillary column $\quad(30 \mathrm{~m} \quad$ DB-WAX $\times 0.25 \mathrm{~mm} \quad$ i.d.; $0.25 \mu \mathrm{m}$ film thickness).

5. FT-IR spectroscopy - the bio-oil was applied as a cast film between two $\mathrm{KBr}$ windows. FT-IR spectra of the chars were obtained after mixing with $\mathrm{KBr}$ ( $\mathrm{KBr}$ pellet).

\section{Results and discussion}

\subsection{Feed materials characteristics}

\subsubsection{Thermogravimetric analysis}

Thermogravimetric analysis was used for determining the residual moisture and to define the operating temperature for ther- mal degradation of sludge in the flash-pyrolysis reactor. The weight loss up to $200{ }^{\circ} \mathrm{C}(1.5,3.7$ and $5.3 \mathrm{wt} \%$ for sludges AKP, DIG and OLDA, respectively (see Table 1)) is due to the release of free and physically bounded water. Most of the combustible matter is degraded between 200 and $500^{\circ} \mathrm{C}$. DTG-curves result for all sludges under study in one dominant peak with $T_{\max }$ at about $320^{\circ} \mathrm{C}$ and a $T_{\text {shoulder }}$ at about $450{ }^{\circ} \mathrm{C}$.

The DTG profile for AKP reveals a stepwise degradation up to $600{ }^{\circ} \mathrm{C}$ with minor losses of water. Mass loss for DIG sludge starts almost immediately and occurs over a broad temperature range with an extra mass release at enhanced temperature $\left(600{ }^{\circ} \mathrm{C}-\right.$ $700^{\circ} \mathrm{C}$ ) which reflects the presence of high molecular weight compounds. The evolution of the DTG profile is less pronounced.

For OLDA, the release of water is more resolved from the thermal degradation process.

All three sludges can also be differentiated with respect to their fixed carbon formation: 20\% (AKP), 8\% (DIG), 18\% (OLDA).

The ash content of AKP sludge and OLDA sludge is $25.0 \%$ and $27.3 \%$ respectively. The higher amount of ash content in DIG sludge was caused by anaerobic digestion, where part of the organic matter was converted to bio-gas.

Since TGA is dynamic experiment and pyrolysis is static experiment, it is decided to select $500{ }^{\circ} \mathrm{C}$ as pyrolysis working temperature.

\subsubsection{Ultimate analysis}

The results of ultimate analysis of studied sludges are summarized in Table 1. Amounts of carbon and nitrogen in the DIG sludge are lower compared to the two other sludges because compounds with these elements are released during anaerobic digestion (carbon in bio-gas as $\mathrm{CH}_{4}$ and $\mathrm{CO}_{2}$ and nitrogen in sludge liquor as $N_{\mathrm{am}}$ mon). A relatively high amount of sulphur in OLDA sludge is caused by the characteristics of the treated (co-treatment of urban waste waters).

The total amount of $\mathrm{C}, \mathrm{H}, \mathrm{N}, \mathrm{S}$ and $\mathrm{O}$ from the ultimate analysis fits well with the amount of mass losses from thermogravimetric analysis. The high $\mathrm{H} / \mathrm{C}$ ratio value indicates a high content of aliphatic hydrocarbon compounds in these sludges, while the relatively low amounts of oxygen is an indication for a minor fraction of polar compounds present in sludges. Because of the high $\mathrm{N} / \mathrm{C}$ ratio, these sludges could be of great interest in view of further valorisation of the obtained bio-oil for products with added value.

Table 1

Characteristics of the sewage sludge.

\begin{tabular}{lrrr}
\hline & AKP & DIG & OLDA \\
\hline TGA analysis $(w t \%)^{a}$ & & & \\
Moisture & 1.5 & 3.7 & 5.3 \\
Volatile matter & 53.8 & 40.5 & 49.0 \\
Fixed carbon & 19.7 & 8.3 & 18.4 \\
Ash & 25.0 & 47.5 & 27.3 \\
Ultimate analysis (wt\%) & $a$ & & \\
Carbon & & 27.6 & 38.8 \\
Hydrogen & 39.9 & 4.4 & 5.6 \\
Nitrogen & 5.9 & 3.5 & 6.0 \\
Oxygen & 7.9 & 19.4 & 3.4 \\
Sulphur & 23.5 & 1.0 & 3.0 \\
H/C molar ration & 0.7 & 1.9 & 0.4 \\
O/C molar ration & 1.8 & 0.53 & 0.13 \\
N/C molar ration & 0.44 & 0.11 & \\
Calorific value $(M J / k g)^{a}$ & 0.17 & & 15.4 \\
Calorimetric analysis & & 8.8 & 15.0 \\
Net calorific value & 17.1 & 8.6 & \\
\hline
\end{tabular}

\footnotetext{
a As prepared (dried at $105^{\circ} \mathrm{C}$, ground).
} 


\subsubsection{Calorific value determination}

The calorific values of the dried sludges are in line with mass loss values from thermogravimetric analysis and ultimate analysis. Lower amounts of mass losses relate to lower calorific value. The lowest HHV and net calorific value can be assigned to the DIG sludge $(8.8 \mathrm{MJ} / \mathrm{kg}, 8.6 \mathrm{MJ} / \mathrm{kg})$, which has the lowest amounts of combustible matter (48.8\%) and the highest ash content. AKP and OLDA sludge have similar HHV's (17.1, 15.4 MJ/kg) and net calorific values ( 16.5 and $15.0 \mathrm{MJ} / \mathrm{kg}$ ) which is in line with their similar volatile matter content. The calorific values observed for AKP and OLDA sludge are in line with other conventional and non-conventional fuels such as low rank coal, paper and wood [15].

\subsection{Pyrolysis products - general features}

In each experiment, char and pyrolytic oil (bio-oil) fraction yields are determined as dry ash free mass and the gas fraction yield is calculated by mass balance. The presented values correspond with the average value of two pyrolysis experiments.

The pyrolysis product yields obtained from 3 types of sewage sludge are shown in Table 2. Some pyrolysis liquids consist of an aqueous and an oil fraction. In case of DIG sludge both, oil and

Table 2

Pyrolysis products.

\begin{tabular}{lccc}
\hline Yield (wt\%) & AKP sludge $^{\mathrm{a}}$ & DIG sludge $^{\mathrm{a}}$ & OLDA sludge $^{\mathrm{a}}$ \\
\hline Bio-oil (wt\%) & & & \\
Vessel [oil] & $29.4 \pm 1.5$ & $9.4 \pm 2.0$ & $24.4 \pm 2.2$ \\
Vessel [aq.phase] & - & $9.4 \pm 0.5$ & \multicolumn{1}{l}{} \\
Cold finger [oil] & $2.7 \pm 0.4$ & - & $1.3 \pm 1.3$ \\
Cold finger [aq. phase] & $11.0 \pm 0.5$ & $2.9 \pm 2.3$ & $2.8 \pm 2.8$ \\
Mix solids + oil & - & $5.0 \pm 0.3$ & - \\
Bio-oils in total & $43.1 \pm 0.7$ & $26.7 \pm 1.0$ & $28.5 \pm 1.9$ \\
Solids (wt\%) & $35.6 \pm 0.5$ & $56.0 \pm 0.1$ & $42.6 \pm 1.1$ \\
Gas (wt\%) & $21.3 \pm 1.2$ & $17.3 \pm 1.1$ & $28.9 \pm 2.9$ \\
Bio-oil (wt\%, daf basis) & & & \\
Vessel [oil] & & $18 \pm 3.9$ & $33.6 \pm 3.0$ \\
Vessel [aq.phase] & $39.3 \pm 2.0$ & $17.8 \pm 0.9$ & - \\
Cold finger [oil] & - & - & $1.8 \pm 1.8$ \\
Cold finger [aq. phase] & $14.7 \pm 0.6$ & $5.5 \pm 0.6$ & $3.8 \pm 3.8$ \\
Mix solids + oil & - & $9.6 \pm 0.5$ & - \\
Bio-oils in total & $57.5 \pm 0.9$ & $50.9 \pm 1.9$ & $39.2 \pm 2.5$ \\
Solids (wt\%, daf basis) ${ }^{\mathrm{b}}$ & $14.1 \pm 0.7$ & $16.2 \pm 0.2$ & $21.0 \pm 1.5$ \\
Gas (wt\%, daf basis) $^{\mathrm{b}}$ & $28.4 \pm 1.6$ & $32.9 \pm 2.1$ & $39.8 \pm 4.1$ \\
Water content in vase $(v / v \%)$ & $10.3 \pm 1.7$ & $78.7 \pm 0.3$ & $17.0 \pm 1.0$
\end{tabular}

a The values correspond with the average value of two pyrolysis experiments.

b The term 'daf' represents dry ash free basis. aqueous fractions, are observed as two separated layers in the condensation vessel. For AKP and OLDA sludge, an oil and an aqueous phase is found only in the cold finger condensate. Important is that these two phases are well separable, in contrary with pyrolysis liquids obtained from other biomass materials. Oil and aqueous fractions are separated and analyzed as such.

Additionally one more product was obtained during pyrolysis of DIG sludge: a mixture of oil and solids (collected in the connection pipe connecting reactor and condensation vessel). This mixture has a high calorific value and is classified as one of "bio-oils" products.

The amount of water in the bio-oils was determined by azeotropic distillation. The water content for bio-oil obtained by pyrolysis of AKP sludge is $10.3 \%$, for OLDA sludge $17.0 \%$. These values are significantly lower than the water content of bio-oils obtained from pyrolysis of other biomasses which ranges between 20 and $40 \%$ $[11,13]$.

\subsubsection{Calorific value determination}

Highest heating values (HHV) as well as net calorific values of pyrolysis products are reported in Table 3. HHV of the produced oils range from 23.9 to $29.0 \mathrm{MJ} / \mathrm{kg}$-oil, net calorific values range from 23.2 to $28.1 \mathrm{MJ} / \mathrm{kg}$-oil and are invert proportional with the water content of bio-oils: the highest HHV is obtained for the oil fraction from DIG sludge, where the aqueous phase was removed by simple separation, because of a two phase bio-oil production.

HHV's of the chars are 5.2 (DIG), 9.9 (AKP) and 10.6 (OLDA) MJ/ kg-total solids (TS). Net calorific values of the chars are 5.0, 9.6 and $10.1 \mathrm{MJ} / \mathrm{kg}$-TS for respectively DIG, AKP and OLDA sludge.

The calorific values of the oils and chars are somewhat lower than reported by Kim [12] (36-39 MJ/kg-oil and 10-21 MJ/kg-TS). The reason for this difference is caused by the used sludge with lower HHV's.

The energy loss values shown in Table 3 are determined from an energy balance that considered the dried sludges and the pyrolysis products (oils and char) as shown by

$E_{\text {loss }}=M_{\mathrm{ds}} \mathrm{HVV}_{\mathrm{ds}}-\left(M_{\mathrm{oil}} \mathrm{HVV}_{\mathrm{oil}}+M_{\mathrm{char}} \mathrm{HVV}_{\mathrm{char}}\right)$

where $M$ and HVV refer to the mass and highest heating values, and the subscript ds refer to the dried sludge. It is assumed that the energy loss values $\left(E_{\text {loss }}\right)$ are related to the energy associated with the gas phase [12]. No experimental data is available for the energy of vented gases at this moment. " $E_{\text {loss }}$ " can be recuperated for sustaining a continuous pyrolysis system at its working temperature and if needed, used for other purposes, like drying the biomass or production of syngas (see Table 3 ).

Table 3

Calorific values of the sludges and the pyrolysis products.

\begin{tabular}{|c|c|c|c|c|c|c|c|}
\hline \multirow[t]{2}{*}{ Sample } & & \multicolumn{2}{|l|}{ AKP sludge } & \multicolumn{2}{|c|}{ DIGESTED sludge } & \multicolumn{2}{|l|}{ OLDA sludge } \\
\hline & & $\begin{array}{l}\text { HHV/NET (MJ/ } \\
\mathrm{kg})\end{array}$ & Energy $[\mathrm{E} * \mathrm{M}](\mathrm{MJ})$ & $\begin{array}{l}\text { HHV/NET (MJ/ } \\
\mathrm{kg})\end{array}$ & Energy $[\mathrm{E} * \mathrm{M}](\mathrm{MJ})$ & $\begin{array}{l}\text { HHV/NET (MJ/ } \\
\mathrm{kg})\end{array}$ & Energy $[\mathrm{E} * \mathrm{M}](\mathrm{MJ})$ \\
\hline Sludge & Input & $\begin{array}{l}17.1 \\
16.5\end{array}$ & 3.415 & $\begin{array}{l}8.8 \\
8.6\end{array}$ & 1.767 & $\begin{array}{l}15.4 \\
15.0\end{array}$ & 3.084 \\
\hline Bio-oil & Vessel [oil] & $\begin{array}{l}24.7 \\
24.2\end{array}$ & 1.455 & $\begin{array}{l}27.9 \\
27.6\end{array}$ & 0.527 & $\begin{array}{l}23.9 \\
23.2\end{array}$ & 1.167 \\
\hline & Cold finger [aq. + oil phase] & $\begin{array}{l}15.7 \\
14.7\end{array}$ & 0.429 & $*$ & & * & \\
\hline & Cold finger [only oil phase] & $\begin{array}{l}29.0 \\
28.1\end{array}$ & 0.157 & * & & * & \\
\hline & Mix solids + oil & & & $\begin{array}{l}20.7 \\
20.3\end{array}$ & 0.209 & & \\
\hline Pyrolytic solids & Pyrolytic solids & $\begin{array}{l}9.9 \\
9.6\end{array}$ & 0.703 & $\begin{array}{l}5.2 \\
5.0\end{array}$ & 0.584 & $\begin{array}{l}10.6 \\
10.1\end{array}$ & 0.902 \\
\hline Gas & “Energy loss" (Eq. (1)) & 15.7 & 1.039 & 13.0 & 0.737 & 17.5 & 1.152 \\
\hline
\end{tabular}

*Not determined because of too small amounts of samples. 
Table 4

Ultimate analysis of produced bio-oils.

\begin{tabular}{|c|c|c|c|c|c|c|}
\hline \multirow[t]{2}{*}{ Ultimate analysis ${ }^{\mathrm{a}}(\mathrm{wt} \%)$} & \multicolumn{2}{|l|}{ AKP } & \multicolumn{2}{|l|}{ DIG } & \multicolumn{2}{|l|}{ OLDA } \\
\hline & AKP OV & AKP CF oil & DIG OV[aq.] & DIG CF oil & OLDA OV & OLDA CF oil \\
\hline Carbon & 65.5 & 68.4 & 69.0 & 73.4 & 54.1 & 58.8 \\
\hline Hydrogen & 8.9 & 8.7 & 9.4 & 9.5 & 8.1 & 8.8 \\
\hline Nitrogen & 11.1 & 9.8 & 6.1 & 8.0 & 9.6 & 8.3 \\
\hline Oxygen & 13.9 & 10.3 & 14.3 & 6.7 & 25.9 & 20.7 \\
\hline Sulphur & 0.7 & 2.7 & 1.2 & 2.4 & 2.4 & 3.4 \\
\hline $\mathrm{H} / \mathrm{C}$ ratio & 1.63 & 1.53 & 1.64 & 1.56 & 1.79 & 1.79 \\
\hline $\mathrm{O} / \mathrm{C}$ ratio & 0.16 & 0.11 & 0.16 & 0.07 & 0.36 & 0.26 \\
\hline $\mathrm{N} / \mathrm{C}$ ratio & 0.14 & 0.12 & 0.08 & 0.09 & 0.15 & 0.12 \\
\hline
\end{tabular}

a Results normalized to $100 \%$.

\subsection{Bio-oils}

\subsubsection{Ultimate analysis}

The results of ultimate analysis of produced bio-oils are shown in Table 4. Because of losses of volatiles during sample loading, a normalization factor is included.

Percentages of elements converted to bio-oil vs. biomass are calculated (Table 5).

The $\mathrm{H} / \mathrm{C}$ ratio of bio-oil comparing to $\mathrm{H} / \mathrm{C}$ ratio of sludge slightly decreases in cases of AKP and DIG sludge. This indicates higher concentration of unsaturated and aromatic compounds in bio-oils then in sludges.

$\mathrm{H} / \mathrm{C}$ ratio of bio-oils produced from OLDA sludge reaches the highest values which reflect the highest amount of aliphatic carbon chains in these bio-oils.

The rather low amounts of oxygen in bio-oil can be interpreted as low concentration of polar functionalities in these bio-oils.

\subsubsection{FT-IR spectroscopy and GC-MS analyses}

Bio-oils from pyrolysis of sewage sludge are also studied by FTIR and GC-MS analysis. Since only OV fraction of bio-oils obtained by pyrolysis of AKP and OLDA sludge have significant yield, only these IR spectra are reported (Fig. 1a and b). Both OV and CF phases of bio-oil obtained from AKP and OLDA sludge are analyzed by GCMS (Fig. 2a-d).

Pyrolytic oils are complex mixtures consisting of organic compounds with wide variety of chemical funcionalities. The groups of organic compounds in bio-oils identified by GC-MS are reported in Table 6. The identified compounds can be grouped into the following classes: oxygenated hydrocarbons such as carboxylic acids and alcohols; nitrogenous compounds such as amides, amines and nitriles; compounds containing sulphur such as sulphides and sulphoxides; and hydrocarbons. Also steroids such as cholestene, cholestadiene and cholestanol are present.

Each group can be also classified into aliphatic, cyclic and aromatic compounds (also given in Table 6). Sulphur compounds are only detected as aliphatic species.

Generally, pyrolysis of these sludges yields bio-oils which contain significant amounts of oxygenated and nitrogenous compounds.

It can be seen, that IR patterns of produced bio-oils are similar, revealing that their corresponding functional groups distribution

Table 5

Elemental fraction from sludge incorporated in bio-oil, pyrolytic solid and gas.

\begin{tabular}{|c|c|c|c|c|c|c|c|c|c|}
\hline \multicolumn{10}{|c|}{ Elements incorporated in bio-oils (\%) } \\
\hline & AKP OV & AKP CF oil & Total AKP & DIG OV [aq.] & DIG CF & Total DIG & OLDA OV & OLDA CF oil & Total OLDA \\
\hline Carbon & 48.2 & 4.6 & 52.8 & 47.1 & 7.7 & 54.8 & 34 & 6.1 & 40.1 \\
\hline Hydrogen & 44.4 & 4.0 & 48.4 & 40.2 & 6.3 & 46.5 & 35.1 & 6.3 & 41.4 \\
\hline Nitrogen & 41.2 & 3.3 & 44.5 & 32.8 & 6.6 & 39.4 & 39.1 & 5.6 & 44.7 \\
\hline Oxygen & 17.3 & 1.2 & 18.5 & 13.9 & 1.0 & 14.9 & 27 & 3.6 & 30.7 \\
\hline Sulphur & 29.4 & 10.4 & 39.8 & 22.6 & 7.0 & 29.6 & 19.5 & 9.2 & 28.4 \\
\hline \multicolumn{10}{|c|}{ Elements incorporated in pyrolytic solids (\%) } \\
\hline & & & AKP & & & DIG & & & OLDA \\
\hline Carbon & & & 24.5 & & & 33.6 & & & 32.1 \\
\hline Hydrogen & & & 12.1 & & & 9.6 & & & 13.7 \\
\hline Nitrogen & & & 19.8 & & & 28.9 & & & 29.1 \\
\hline Oxygen & & & 24.8 & & & 17.9 & & & 26.2 \\
\hline Sulphur & & & 55.9 & & & 23.2 & & & 45.4 \\
\hline \multicolumn{10}{|c|}{ Elements incorporated in gas (\%) } \\
\hline & & & $A K P$ & & & DIG & & & OLDA \\
\hline Carbon & & & 22.7 & & & 11.6 & & & 27.8 \\
\hline Hydrogen & & & 39.5 & & & 43.9 & & & 44.9 \\
\hline Nitrogen & & & 35.7 & & & 31.7 & & & 26.2 \\
\hline Oxygen & & & 56.7 & & & 67.2 & & & 43.1 \\
\hline Sulphur & & & 4.3 & & & 47.2 & & & 26.2 \\
\hline
\end{tabular}

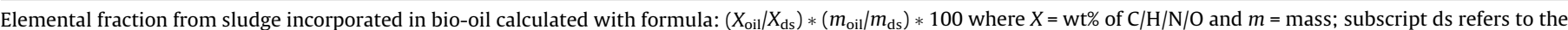
dried sludge and oil to bio-oil; the value $\left(m_{\text {oil }} / m_{\mathrm{ds}}\right) * 100$ correspond with the yield in Table 2 .

e.g. carbon AKP sludge incorporated in AKP OV bio-oil: $(65.5 \% / 39.9 \%) * 29.4 \%=48.2 \%$.

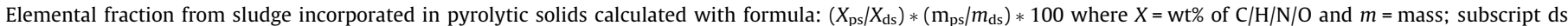
refers to the dried sludge and ps to pyrolytic solids; the value $\left(m_{\mathrm{ps}} / m_{\mathrm{ds}}\right) * 100$ correspond with the yield in Table 2 .

e.g. carbon AKP sludge incorporated in AKP pyrolytic solids: $(27.5 \% / 39.9 \%) * 35.6 \%=24.5 \%$. 

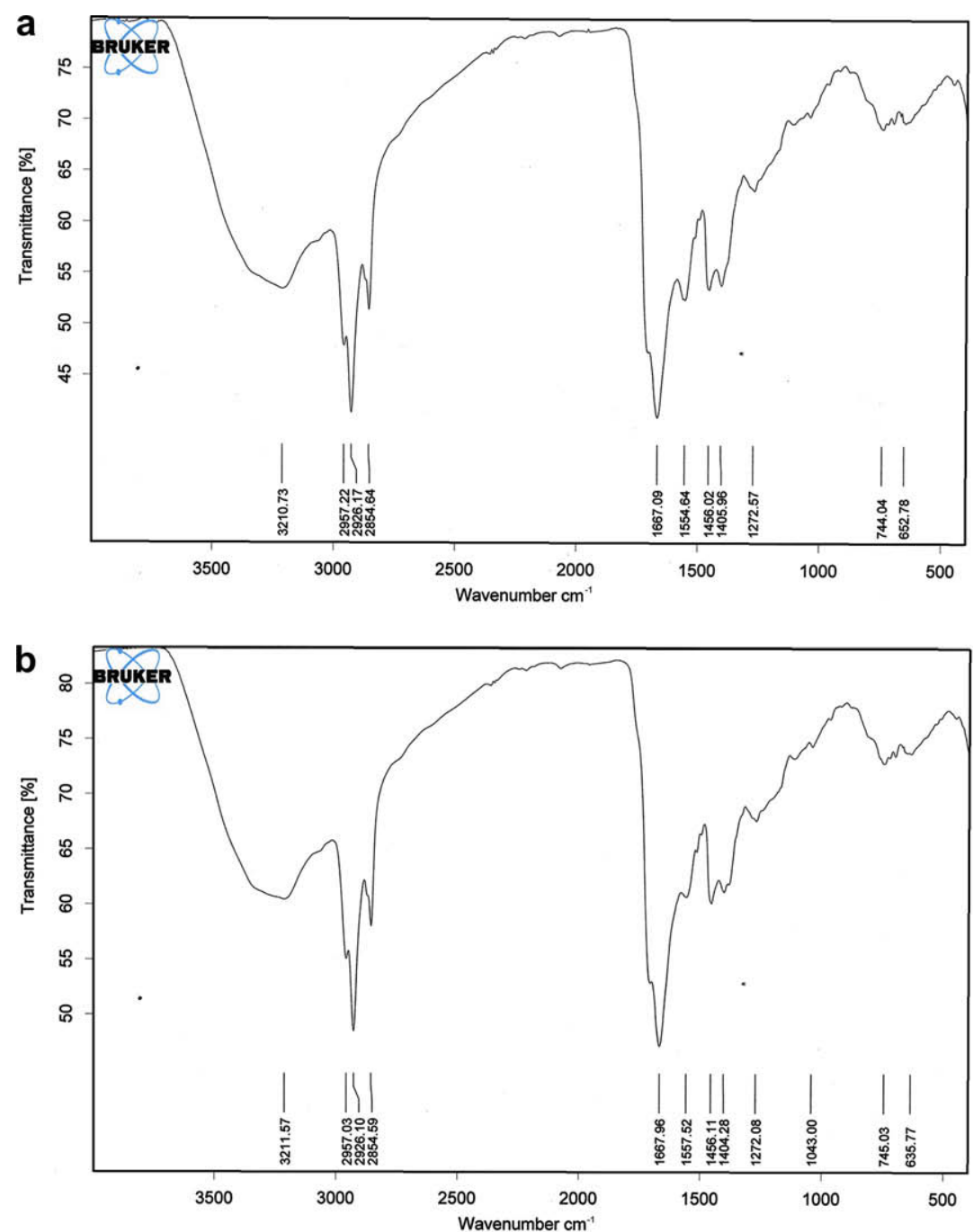

Fig. 1. FT-IR spectra of produced bio-oils from (a) OV fraction of AKP sludge and (b) OV fraction of OLDA sludge.

are similar. The presence of a large intense band of intermolecular hydrogen bonds of $\mathrm{O}-\mathrm{H}$ stretching vibration at $3400 \mathrm{~cm}^{-1}$ can be assigned to carboxylic group and hydroxyl functionalities. The presence of carboxylic acids is further confirmed by the absorption band around $1700 \mathrm{~cm}^{-1}$ (typical stretching vibration from carboxylic acids). This band is more intense in case of bio-oils from OLDA sludge, reflecting the higher concentration of carboxylic acids. Absorption due to $\mathrm{C}-\mathrm{O}$ vibrations are also found between 1300 and $900 \mathrm{~cm}^{-1}$. GC-MS analysis shows that bio-oils from AKP sludge contain carboxylic acids ( 36 to $39 \%$ ), bio-oils produced from OLDA sludge contain $76 \%$ carboxylic acid in case of OV phase and $64 \%$ in case of $\mathrm{CF}$ phase. Most of these carboxylic acids are long straight chain fatty acids (retention time-RT 19.32-25.32 min). This is in good agreement with literature. Karayildirim [16] reported that raw sludge produced oil with $65 \%$ of straight chain carboxylic acids.

Boocock [17] reported that long chain carboxylic acids survived the pyrolysis and resulted in an increase in viscosity of the oil. Biooil of OLDA sludge shows higher viscosity than the oil produced from AKP sludge which again is in good agreement with prior studies [17].

Other oxygenated compounds detected by GC-MS in bio-oil are mostly phenolics (RT 14.86-16.33 min). FT-IR spectra features predict the presence of amides and amines by superposition of an absorption band around $3200 \mathrm{~cm}^{-1}(\mathrm{~N}-\mathrm{H}$ stretching). The pres- ence of secondary amides is further confirmed from the absorption band at $1570-1530 \mathrm{~cm}^{-1}$. The spectral window 1500 $1680 \mathrm{~cm}^{-1}$ could be assigned to phenols and amides. Specific absorption bands within this spectral window are more dominant in case of bio-oil from AKP sludge, which is confirmed by GC-MS results.

Presence of nitrogenous compounds ranges from $27 \%$ to $29 \%$ in bio-oils produced from AKP sludge and from $11 \%$ to $12 \%$ in bio-oils produced from OLDA sludge. The main nitrogenous compounds observed in the pyrolysate of studied sludges are secondary amides. Bio-oils obtained by pyrolysis of AKP sludge consist of $21 \%$ (OV phase) and 10\% (CF phase) amides. Presence of amides in bio-oils from OLDA sludge amounts to 7\%. Amines are present by $5 \%$ in OV phase and $12 \%$ in CF phase in bio-oils obtained by pyrolysis of AKP sludge. Bio-oils from OLDA consist of $2.5 \%$ and $3 \%$ of amines in OV and CF phase respectively.

FT-IR spectra give also an indication for the presence of nitriles $(\mathrm{C} \equiv \mathrm{N})$ in the spectral region $2260-2210 \mathrm{~cm}^{-1}$, which is further confirmed by GC-MS. Higher concentration of nitriles appears in CF phase (4.1\% and $2.8 \%$ in pyrolytic bio-oils from AKP and OLDA sludge, respectively). These nitriles are formed by dehydration reactions of peptide bonds present in the protein fraction of the sludge.

Additional compounds detected by GC-MS are sulphur compounds, especially identified in CF phase, which is in line with re- 

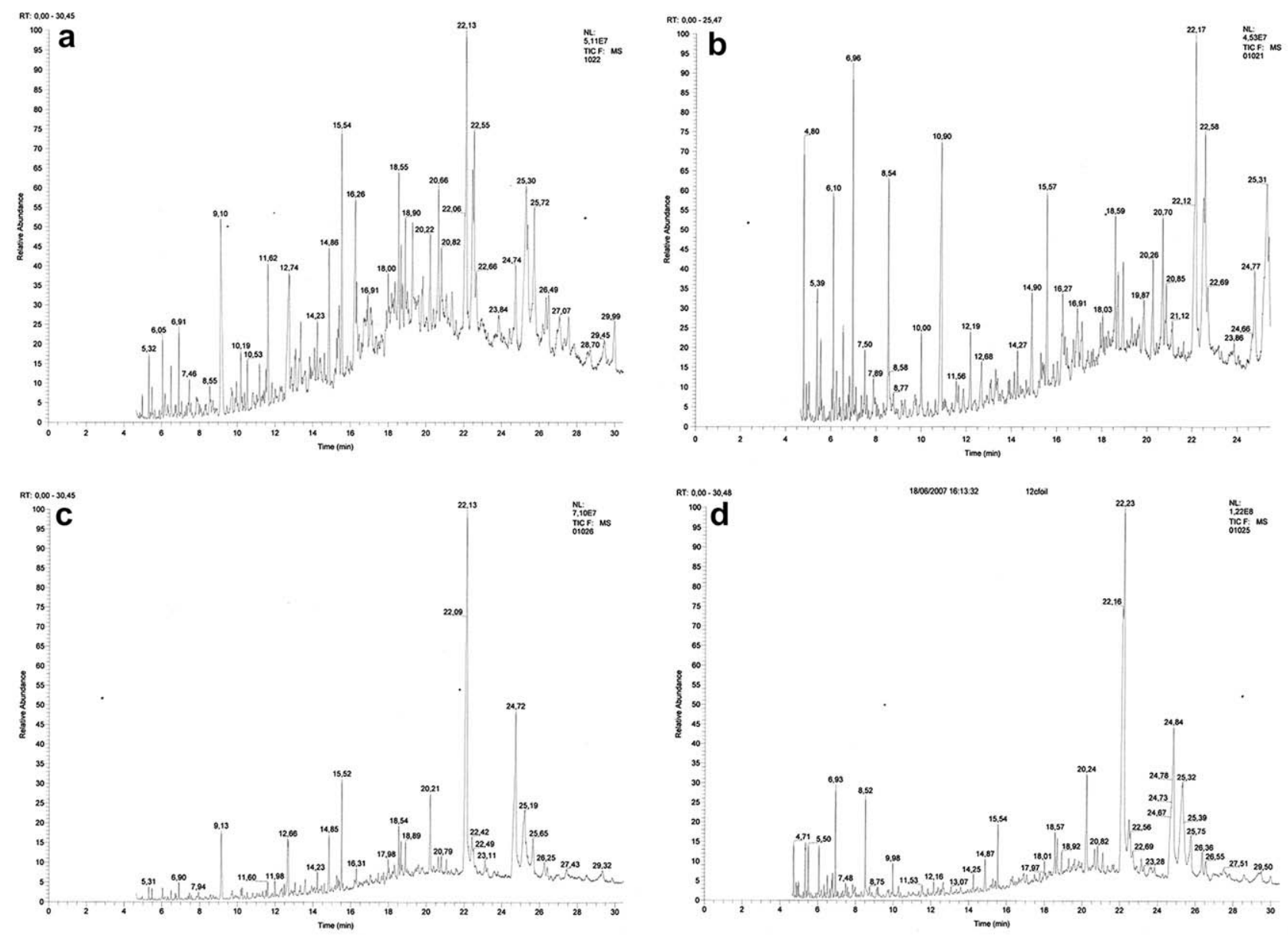

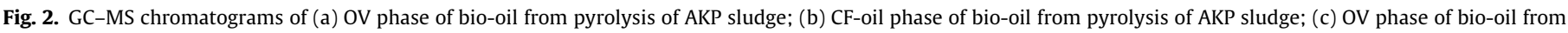
pyrolysis of OLDA sludge and (d) CF-oil phase of bio-oil from pyrolysis of OLDA sludge.

Table 6

GC-MS analysis of the produced bio-oils from AKP and OLDA sludge.

\begin{tabular}{|c|c|c|c|c|}
\hline GC-MS analysis $(\mathrm{wt} \%)^{\mathrm{a}}$ & $\mathrm{AKP}-\mathrm{OV}$ & AKP - CF oil & OLDA - OV & OLDA - CF oil \\
\hline \multicolumn{5}{|l|}{ Classified by composition } \\
\hline \multicolumn{5}{|l|}{ Oxygenated compounds } \\
\hline Fatty acids & 39 & 36 & 76 & 64 \\
\hline Alcohols & 8.9 & 7.1 & 8.0 & 3.8 \\
\hline Others & 2.5 & 1.6 & 0.0 & 0.4 \\
\hline Total oxygen compounds & 51 & 44 & 84 & 68 \\
\hline \multicolumn{5}{|l|}{ Nitrogenated compounds } \\
\hline Amides & 21 & 10 & 7 & 7 \\
\hline Amines & 5 & 12 & 2.5 & 3.0 \\
\hline Nitriles & 2.8 & 4.1 & 1.9 & 2.8 \\
\hline Total nitrogenated compounds & 29 & 26 & 11 & 13 \\
\hline Sulphur compounds & 1.3 & 8.7 & 0 & 5.7 \\
\hline Hydrocarbones & 4.1 & 10.9 & 0.8 & 6.3 \\
\hline Steroids & 6.9 & 2.6 & 3.4 & 3.7 \\
\hline Not identified & 8.3 & 6.9 & 1.0 & 4.2 \\
\hline \multicolumn{5}{|l|}{ Classified by structure } \\
\hline Aliphatic & 52 & 52 & 79 & 77 \\
\hline Cyclic & 21 & 20 & 7 & 9 \\
\hline Aromatic & 19 & 21 & 14 & 10 \\
\hline Not identified & 8 & 7 & 1 & 4 \\
\hline
\end{tabular}

a Results normalized to $100 \%$.

sults of ultimate analysis. Minor amounts are detected in OV phase $(<1.5 \%)$.

Long aliphatic carbon chains are verified within the IR spectral window $3000-2800 \mathrm{~cm}^{-1}$, dedicated to $\mathrm{C}-\mathrm{H}$ stretching vibrations, as well as the deformation bands between 1470 and $1430 \mathrm{~cm}^{-1}$, and rocking $\mathrm{CH}_{2}$ vibrations stretching at $722 \mathrm{~cm}^{-1}$. Most of these aliphatic carbon chains are structural moieties of fatty acids. Presence of pure hydrocarbons is limited (0.8-10.9\%). 
Table 7

Characteristics of solids.

\begin{tabular}{lccc}
\hline TGA analysis (wt\%) & AKP & DIG & OLDA \\
\hline Ash & 57.9 & 75.1 & 58.1 \\
Ultimate analysis of chars (wt\%) & & & \\
Carbon & 27.5 & 15.6 & 29.2 \\
Hydrogen & 2.0 & 1.4 & 1.8 \\
Nitrogen & 4.4 & 1.7 & 4.1 \\
Oxygen & 16.4 & 14.6 & 14.4 \\
Sulphur & 1.1 & 1.5 & 3.2 \\
H/C molar ratio & 0.87 & 1.08 & 0.74 \\
O/C molar ratio & 0.45 & 0.70 & 0.37 \\
N/C molar ratio & 0.14 & 0.09 & 0.12 \\
\end{tabular}

The absorption bands in the spectral region $3100-3000 \mathrm{~cm}^{-1}$ (sp2 C-H stretching vibration) can be related to the aromaticity and unsaturation of the bio-oil. Minor concentration of aromatics (ethylbenzene and styrene) are identified by GC-MS especially in CF-oil phases.

Last group detected by GC-MS are steroids (RT 26.42-30.0). Their presence in bio-oils produced from sludge was also reported by Dominguez $[6,18]$.

\subsection{Solids}

The solids obtained from pyrolysis of sewage sludge could be, either incinerated for energy recuperation, disposed off by landfilling or used as adsorbents [16]. The potential use of solids in these three options depends on their chemical characteristics. Some properties of pyrolytic solids are therefore determined, such as ash content (TGA), the calorific value, CHNS-O element analysis and FT-IR features.

\subsubsection{Thermogravimetric and ultimate analysis}

The high ash content (see Table 7) together with low calorific value (Table 3 ) make chars unattractive for use in incineration. Results of ultimate analysis also show that chars have relatively very high amounts of sulphur. Percentage of elements which are incorporated in the pyrolytic solids is calculated by comparing results of ultimate analysis of input material. Most of the organic components are converted to pyrolysis bio-oils or gases, (for example pyrolytic solids contains $12.1 \%, 9.6 \%$ and $13.7 \%$ of hydrogen for AKP, DIG and OLDA, respectively).

\subsubsection{FT-IR analysis}

The IR spectra reveal the presence of the characteristics patterns of alumina-silicates (stretching vibration at 3500$3300 \mathrm{~cm}^{-1}, \quad 1650-1600 \mathrm{~cm}^{-1}, \quad 550-450 \mathrm{~cm}^{-1}$ and $1100-$ $\left.1000 \mathrm{~cm}^{-1}\right)$.

Spectra of the char from pyrolysis of OLDA and DIG sludge show also the specific absorption bands at 1430 for carbonates. The diagnostic IR bands at 875 and at $715 \mathrm{~cm}^{-1}$ can be assigned to $\mathrm{CaCO}_{3}$. (Confirmation - overtones at $2500 \mathrm{~cm}^{-1}$ and $1800 \mathrm{~cm}^{-1}$ ).

\section{Conclusions}

Our study confirms that sewage sludge is suitable feed material for production of bio-oil by flash pyrolysis. Yields of bio-oils based on ash free biomass range from $39.2 \%$ to $57.5 \%$. The best results, concerning to pyrolysis products, are obtained with AKP sludge: $57.5 \%$ of organic matter is converted to bio-oil with calorific value of $24.7 \mathrm{MJ} / \mathrm{kg}$ and also the water content was the lowest: $10.3 \%$.

FT-IR and GC-MS analysis demonstrate that bio-oil is a complex mixture with a variety of components. However, both analyses prove that the fraction of aromatic compounds is low. GC-MS analyses confirm that fatty acids are the most dominant group. In the application of the oil as a fuel, it is preferred that the compounds in the oil are straight chain hydrocarbons as they have a high heating value [19]. Low aromatic and polar content is also desirable for energy valorization.

Utilization of bio-oil produced from pyrolysis of sewage sludge as feed material seems also possible. High distribution of fatty acid can lead to extraction of these acids and their utilization in chemical industry. High presence of nitrogenous compounds can improve added value of bio-oils by isolation of these compounds from the bio-oil. Esterification is also another option.

FT-IR analysis of chars shows that chars have similar IR features as notified alumosilicates. Alumosilicates are used as adsorbents; utilization of pyrolytic solids as adsorbents should be further studied for potential added value of chars. The high ash content and low calorimetric value make them unattractive for use in incineration.

\section{Acknowledgments}

The authors thank J. Kaelen for his dedicated contribution in the construction of the semi-continuous home-built pyrolysis installation, O. Vodicka for OLDA sludge supply, and M. Vanhamel for doing the FT-IR analysis. This work fits into an association bursary between Xios and University Hasselt, and also a bilateral cultural cooperation programme between the Flemish Community and the Czech Republic.

\section{References}

[1] Eckenfelder WW. Industrial water pollution control. Boston: McGraw-Hill; 2000.

[2] Jeníček P. Výpočty v technologii vody II. Praha: Skriptum VŠCHT Praha; 1999

[3] Chudoba J, Dohányos M, Wanner J. Biologické čištění odpadních vod. Praha: SNTL; 1991.

[4] Gonzales MV, Asaadi, M., Ouki S. Effect of sludge composition on the degree of stabilization and gas production during mesophilic anaerobic digestion (MAD) Report of research and technology spencer house, UK.

[5] Summary of EU waste legislation on sewage sludge: <http://ec.europa.eu/ environment/waste/sludge/index.htm>.

[6] Dominguez A, Menendez JA, Inguanzo M, Pis JJ. Investigation into the characteristics of oils produced from microwave pyrolysis of sewage sludge. Fuel Process Technol 2005;86:1007-20.

[7] Muhlen HJ, Wanzl W, Van Heek KH. Characterization of carbon containing materials with respect to pyrolysis and gasification. In: Proceedings of an international conference for pyrolysis and gasification, Luxembourg; 1989, p. 72-84.

[8] Doshi VA, Buthaluru HB, Bastow T. Investigations into the control of odour and viscosity of biomass oil derived from pyrolysis of sewage sludge. Fuel Process Technol 2005;86:885-97.

[9] Caballero JA, Font R, Marcilla A, Conesa JA. Characterization of sewage sludges by primary and secondary pyrolysis. J Anal Appl Pyrol 1997;40-41:443-50.

[10] Inguanzo M, Dominguez A, Menendez JA, Blanco CG, Pis JJ. On the pyrolysis of sewage sludge: the influence of pyrolysis conditions on solid, liquid and gas fractions. J Anal Appl Pyrol 2001;63:209-22.

[11] Bridgewater AV, Meier D, Radlein D. An overview of fast pyrolysis of biomass. Organ Geochem 1999;30:1479-93.

[12] Kim Y, Parker W. A technical and economic evaluation of pyrolysis of sewage sludge for the production of bio-oil. Biores Technol 2008;99:1409-16.

[13] Cornelissen T, Yperman J, Reggers G, Schreurs S, Carleer R. Flash-co-pyrolysis of biomass with polylactic acid, part 1 . Influence on bio-oil yield and heating value. Fuel 2008:87:1031-41.

[14] DIN 51900-3. Testing of solid and liquid fuels - Determination of gross calorific value by the bomb calorimeter and calculation of the net calorific value.

[15] Perry RH. Perry's chemical engineers handbook. New York (USA): McGrawHill; 1984

[16] Karayildirim T, Yanik J, Yuksel M, Bockhorn H. Characterisation of products from pyrolysis of waste sludges. Fuel 2006;85:1498-508.

[17] Boocock DG, Konar SK, Leung A, Ly LD. Fuels and chemicals from sewage sludge. Fuel 1992;71:1283-9.

[18] Dominguez A, Menendez JA, Inguanzo M, Pis JJ. Production of bio-fuels by high temperature pyrolysis of sewage using conventional and microwave heating. Biores Technol 2006;97:1185-93.

[19] Shen L, Zhang DK. An experimental study of oil recovery from sewage sludge by low-temperature pyrolysis in a fluidized-bed. Fuel 2003;82:465-72. 